\title{
Economics
}

2016; 5(3): 27-45

http://www.sciencepublishinggroup.com/j/eco

doi: 10.11648/j.eco.20160503.11

\section{Asymmetric Technology Diffusion, Nominal Wage Rigidity, and the "New Normal" in China}

\author{
Ge Song \\ Email address: \\ richardsong199224@outlook.com
}

School of Economics, Fudan University, Shanghai, P. R. China

\section{To cite this article:}

Ge Song. Asymmetric Technology Diffusion, Nominal Wage Rigidity, and the "New Normal" in China. Economics. Vol. 5, No. 3, 2016, pp. 27-45. doi: 10.11648/j.eco.20160503.11

Received: May 14, 2016; Accepted: May 30, 2016; Published: June 23, 2016

\begin{abstract}
This paper is based on a growth model that is consistent with salient features of the recent "New Normal" growth experience in China: slowdown of growth rate, low level of inflation and unemployment, decreasing returns on capital investment, extensive reallocation among agriculture, manufacturing and modern service sectors, rising share of consumption, improvement of wealth distribution, and reduced foreign surplus. The building blocks of the theory are asymmetric technology diffusions from FDI firms among various sectors and nominal wage rigidity in the labor market. Due to the asymmetric technology diffusion among different sectors, manufacturing firms enjoy a more rapid productivity progress via the process of learning by doing in a processing on order economy. Thus manufacturing sectors serve as the engine in the past years' economic growth in China. Through the competition in labor market, trends of wage equalization drive the migration of residents from agriculture to manufacturing and modern service sectors. Moreover, with a larger share of processing on order firms, China tends to further enlarge her foreign surplus in a faster pace. However, the result of this paper shows that since the exchange rate reform on July $21^{\text {st }} 2005$, RMB has appreciated accumulatively by $35 \%$, combined with the wage rigidity in labor market, FDI firms in manufacturing sectors face an increasing level of cost in terms of increasing wage expenditure. Incumbent low profitable firms exit and potential entrants with new technology no more settle down. Thus, rapid productivity progress ceases in manufacturing sector. Not only the growth rate slows down, but also large number of unemployed population reallocates back to modern service and agriculture sectors. Dwindling share of manufacturing sectors reduced the foreign surplus by the drops of processing on order infra-firm trade of FDI firms.
\end{abstract}

Keywords: Asymmetric Technology Diffusion, Nominal Wage Rigidity, Reallocation Among Sectors, "New Normal" in China

\section{Introduction}

\subsection{Research Background and Significance of the Subject}

Since the domestic reform and opening-up to the outside world in 1978, trade, like in the nineteenth century, serves as the engine of economic growth in China. With the further participation into the international labor division system, say WTO in 2001, the Chinese economy, in the context of its comparative advantage, went on a path of taking off: sustained acceleration in growth rate, widened ranges of FDI, continued TFP progress, extensive reallocation among agriculture and manufacturing sectors, and constant return to capital investment. However, since the exchange rate reform in 2005, the Chinese currency, RMB, has appreciated accumulatively over $35 \%$ versus USD. Consequently, Export growth drops drastically from an average of 29 percent per annum between 2001 and 2008 to under 10 percent per annum in recent years. Thus the contribution of exports to economic growth, if not negative, seems negligible. While what is even more devastating is that the backward and forward linkages of trade also shrink. As a result, the Chinese economy steps into a phase of "New Normal" with the slowdown of growth rate and TFP progress, low level of inflation and unemployment, decreasing returns on capital investment, extensive reallocation among agriculture, manufacturing and modern service sectors, rising share of consumption, improvement of wealth distribution, and reduced foreign surplus and trade volume.

The concept of "New Normal" was first officially 
mentioned by Mohamed El-Erian, the CEO of PIMCO. Mohamed El-Erian used the concept of "New Normal" to describe the tough process of economic recover from the post-2008 global economic crisis. Ever since the concept of "New Normal" was proposed, myriad interpretations have occurred across countries. The pessimistic viewers contend that "New Normal" is the stage in which the economy cannot flexibly return to its initial equilibrium after external shocks, instead the economy falls into a miserable process of adjustment. On the contrary, the optimistic viewers cast doubt on the opinions from the pessimistic and argue that "New Normal" is an initiative to bid farewell to the unsustainable past while embrace a more promising long-term goal.

The indigenization process of the concept of "New Normal" in China is more rapid than one could ever imagine. In December 2013, the Central Economic Conference of China initially mentioned the concept of "New Normal", emphasizing that rational attitude should be adopted toward the "New Normal" experience in China - a switch from high level of economic growth rate to medium level of economic growth rate. Afterwards, the implication and interpretation of "New Normal" have kept enriching. In May 2014, Chairman $\mathrm{Xi}$ Jinping, during his visit to Henan province, enunciated that the adaptation to the "New Normal" experience should be specific and tailored in terms of a certain country's economic development process. At this time, the implication of "New Normal" has already exceeded the single category of economic growth rate. In November 2014, Chairman Xi Jinping explicated the three major characteristics of the "New Normal" in China in APEC conference: first and foremost, the economic growth rate switches from high level to medium level; second, the economic structure of China is facing a profound adjustment and transition process; third, the engine of economic growth will gradually alternate from massive input of energy and factor to elaboration and innovation. The indigenization of the concept of "New Normal" in China is also hotly debated among scholars. The majority of scholars attribute the "New Normal" experience in China to the voluntary economic structure transition while insisting that the "New Normal" experience is an inevitable phase for China to restructure and update its domestic economy. To be more specific, the current economic transition in China foregrounds more on internal consumption, innovative capacity, environmental protection, and the update of its unsustainable industrial structure. Since then, it's an implicit consensus among many governmental officials and academic scholars that China has already stepped into the phase of "New Normal". The Chinese government also postulates that China's entering the phase of "New Normal" is valid, and therefore enacting relative strategies and policies of economic development. Considering the fact that the "New Normal" experience in China is taken by the government as supportive background of its policy enactment, hence, the elaboration and research on the "New Normal" experience in China is of vital importance.

This paper holds an uncertain view that the "New Normal" experience in China can be attributed to an inevitable process of economic transition: first, the concurrence of the "New Normal" experience in China and China's economic structural transition may be spurious, thus unable to verify whether there exists a causal relation between the two; second, even though it is not spurious regression, the economic structural transition may not be the direct reason for the occurrence of "New Normal" experience in China, i.e., there might exist endogeneity for taking economic structural transition as the independent variable to "New Normal" experience. Different from the point of view above, this paper suggests the reason for the "New Normal" experience in China cannot be found among static variables of the same period; instead, the explanation for "New Normal" experience in China should be delivered from the dynamic view that the accumulative change of some variables might result in the "New Normal" experience in China. Therefore, this paper holds the view that in order to disclose the veil of the "New Normal" experience in China, a dynamic methodology is needed to determine whether the accumulative change of some variables plays the key role in China's entering of the phase of "New Normal".

The train of thoughts of this paper includes: first, this paper summarizes the stylized facts about the "New Normal" experience in China-slowdown of growth rate, low level of inflation and unemployment, decreasing returns on capital investment, extensive reallocation among agriculture, manufacturing and modern service sectors, rising share of consumption, improvement of wealth distribution, and reduced foreign surplus; second, this paper starts from the stylized facts and observe whether there exists accumulative change of a certain variable whose change will reconcile with the "New Normal" experience in China; The finding of this paper is that the direct reason for China's entering of the phase of "New Normal" is attributed to the long-term decrease of technological diffusion from FDI firms and the exacerbating accumulation of nominal wage rigidity in the labor market; third, taking the above two theories as building blocks, this paper constructs an endogenous growth model, whose dynamic equilibrium reconciles with the "New Normal" experience in China; last but not the least, this paper also provides empirical testimonies and econometric methodology to support the theoretical part of this paper.

Based on the theory proposed above, this paper offers a new slant to explain the "New Normal" experience in China: slowdown of growth rate, low level of inflation and unemployment, decreasing returns on capital investment, extensive reallocation among agriculture, manufacturing and modern service sectors, rising share of consumption, improvement of wealth distribution, and reduced foreign surplus. Particularly, referring to its analysis towards the slowdown of the potential economic growth rate in China, this paper provokes critical thinking towards China's optimal position in the trade-off between self-innovation and its enjoy of the overflow of technology spillovers from FDI firms. Moreover, this paper also relates to the idea that what policy China should adopt in order to internalize the positive externality from FDI firms. All the discussions above count much in China's economic prospects. 


\subsection{Literature Review}

The current paper is part of recent literatures arguing that low level of TFP in backwards developing countries is due to their lack of innovation ability. By linking the TFP growth rate to innovation, endogenous growth models shed light on the determinants of TFP growth: R\&D and human capital, the two main engines that propel technology progress and productivity growth [25] [13] [21] (Romer, 1989; Aghion and Howitt, 1998 and Lucas, 1988). However, this question is far from being settled. Even though most of the existing empirical studies are in favor of the notion that domestic $R \& D$ is a crucial determinant of productivity [5] [8] (Coe and Moghadam, 1993; Harhoff, 1998), some recent studies argue that TFP productivity is negatively affected by $R \& D$ expenditure [23] (Madden and Savage, 2000). What I find in this paper is consistent with the recent studies: even though certain firms in those countries attach a large proportion of expenditure into R\&D and use the state-of-art technology, they lack a sufficiently large home market since their products are not in accordance with their comparative advantage. In addition, taking into account of the border effect, their products are also less competitive compared with those produced by firms in developed countries. Thus, innovative as they are, the special period of development rules out the possibility for self-dependent innovation to be the engine for backward economies to take off. Moreover, this paper will illustrate the opinion that as long as one could further its participation into the international labor division systems, even when they are currently located in the low end of international labor division system, with the continuum of technology diffusion and the spillover effects of learning by doing in the manufacturing sector, the realization of sustained economic growth, acceleration of urbanization, progress of total factor productivity, and constant return to capital will never be far away. In addition, during the transitional process, the extensive reallocation among agriculture, manufacturing and modern service sectors serves as a tremendous force to economic growth higher than the innovation rate of developed countries, thus incurring a convergence between developing and developed countries. The past 30 -years economic growth in China is a good proof of the point above.

In order to illustrate the mechanism above, the paper applied a model with heterogeneous level of technology diffusion and learning by doing effects among sectors. For the fact that asymmetric technology diffusion and learning-by-doing effects is stronger in manufacturing sector, firms in manufacturing sector own larger productivity, while for firms in agriculture sector their productivity is lower and normalized to 1 for simplicity. Since the productivity of labor is higher in the urban area, thus wages are higher in urban area than in rural area. Then trends of wage equalization drive the migration of rural residents to urban area and participate in the manufacturing sector, thus enhancing their productivity via learning by doing. During this process, the acceleration of economic growth, urbanization and the progress of TFP have thus achieved. Moreover, since the manufacturing sector is mainly specializing in processing on order, the increasing share of manufacturing sector raises the current account surplus in China, which is consistent with the increasing stock of foreign reserve of the central bank.

This paper is related to the theory of urbanization arguing that the reallocation between agriculture and manufacturing sectors is an important source for TFP progress. The seminal contribution of Lewis (1954), who constructs a model of reallocation from agriculture to industry where the supply of labor in manufacturing is unlimited due to structural overemployment in agriculture [20], is similar in some respects to the current study. Lewis' theory captures aspects of the reallocation between agriculture and industrial sectors, while the focus of this paper is on the reallocation among the agriculture, manufacturing sector, as well as modern service sector in China. Besides Lewis' contribution, there is also a large number of theoretical literatures which suggest that urbanization affects the productivity level in many ways [19] [29] [3] [12] [22] (Landes 1969, Williamson 1986, Burgess and Venables 2004, Henderson 2005, Lucas 2004). Firstly, urbanization provides economies of scale, which allow specialization among firms leading to low cost of production. It also allows specialized services to emerge, such as accounting, management services, and intellectual property management. Economies of scale in cities also reduce transaction costs. High population densities in cities allow both workers with differentiated skills and firms with specific needs to reduce their search cost and mismatch of skills and jobs. Secondly, urbanization enhances the flow of ideas and knowledge due to agglomeration effect. By bringing together large numbers of people, cities facilitate interactions needed to generate, diffuse, and accumulate knowledge. In addition, both economies of scale and agglomeration effect increase the return from investment in human capital. This encourages more investment in human capital. Also public services such as hospitals and universities require a critical mass of consumers to make them economically feasible. The population density of urban areas increases the range of such services and facilitates human capital formation. Thus, urbanization affects both the demand and the supply of human capital. This paper keeps consistent with the point of view above by trying to provide a rationale for igniting the engine of the urbanization process, which is continuum of technology diffusion and learning-by-doing effects.

The current paper is also part of the theory of asymmetric technology diffusion and learning-by-doing effects. In the last decade, studies by Klenow and Rodriguez-Clare (1997), Prescott (1998), Hall and Jones (1999) and Easterly and Levine (2002) among others have illustrated that most of the cross-country differences in the level as well as growth rate of per capita income are explained by differences in the level and growth rate of TFP rather than by capital (physical and human) accumulation [15] [24] [11] [9]. Furthermore, technology is seen as a key determinant of productivity. However, given the fact that a small number of rich countries contribute to most of world's creation of new technology, there is now widespread consensus that the international transfer of technology is an 
important source of domestic productivity growth and ultimately higher living standards [10] [26] [14] (Eaton and Kortum, 1994; Saggi, 2002; Keller, 2002). For example, Keller (2002) insists foreign sources of technology constitute $90 \%$ or even more of domestic productivity growth. In light of this fact, he further argues that international diffusion of technology is essential because it determines the pace at which the world's technology frontier may expand in the future. Similarly, Eaton and Kortum (1994) estimate that foreign R\&D contributed approximately $85 \%$ of productivity growth in France, Germany and the UK in 1988. In the context of developing countries, Coe Helpman and Hoffmaister (1995), estimate that a 1 percent increase in the R\&D capital stock in the industrialized countries raises output in developing countries by 0.06 percent [4]. As for learning by doing effect, it has occupied a central place within economics ever since Arrow (1971) used the concept as a workhorse in his theory of endogenous growth. Arrow conceptualized learning by doing within the actual activity of production, with cumulative gross investment as the catalyst for experience [1]. Nearly two decades later, the role of experience in shaping and driving productivity growth was central in Lucas' (1988) explanations of increasing returns to human capital. Indeed, Lucas (1988, p. 27) argues "on-the-job-training or learning by doing appear to be at least as important as schooling in the formation of human capital." Yang and Borland (1991) furthered this line of thought by theoretically linking the division of labor and learning by doing, highlighting an important source of comparative advantage [31]. This paper mainly focuses on the technology diffusion and learning-by-doing effects in the manufacturing sector, which serves as the engine of the economic growth.

Wage rigidity is always considered as a source of fluctuation in the economic circle. The strong evidence for downward nominal wage rigidity (DNWR) for workers in many OECD countries suggests that wage cutting may be difficult in a low inflation environment [7] [16] [2] (Dickens et al. (2006), Knoppik and Beissinger (2008), and Bewley (1999)). This is consistent with the current Chinese experience. The focus of this paper lies in the effect of wage rigidity to technology diffusion in the manufacturing sector. It is found that due to the rigidity in wage, when the firm's cost soars, neither nominal wage is flexible to adjust nor low level of inflation has a significant role in real wage cutting, thus incurring exit of incumbent firms and deterring entrance of potential new firms with higher level of technology. The nominal wage rigidity on China's domestic labor market can be illustrated by figure 1 . As figure 1 shows, the index of the total wage amount of the urban workers is a measure of the time series characteristics of wage increase, while the index of GDP is a measure of the time series characteristics of the increase of gross domestic product. It's obvious to find that from 2000 to 2014, there exists nominal wage rigidity in China's labor market. Specifically, the index of the total wage amount of urban workers is always above the index of GDP. This manifests that the growth rate of revenue of urban workers exceeds the growth rate of GDP, which is inconceivable on the path of equilibrium state. The only explanation to this aberrant phenomenon is that there exists nominal wage rigidity in China's labor market.

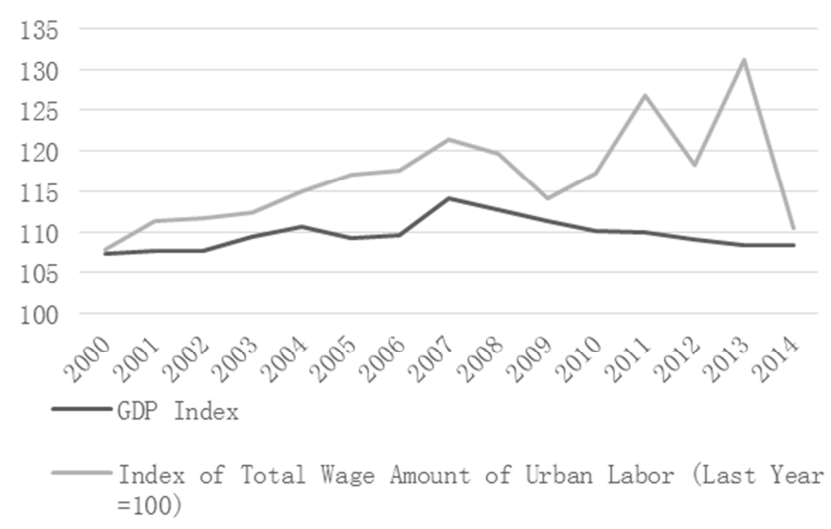

Data Source: National Bureau of Statistics of China.

Figure 1. GDP Index and Index of Total Wage Amount of Urban Labor.

A few recent papers address the issue that why China has accumulated such an enormous amount of foreign surplus. Many of them attribute this to the high saving rate of the Chinese residents. Kuijis (2005) shows that the household and enterprise savings rates in China are, respectively, 11.8 and 8.6 percentage points, which are higher than those in the United States [18]. In the related papers, asymmetric demand, traditional culture, an imperfect financial sector, and lack of welfare and pension benefits are among the rationales proposed as explanations for this [17] (Kraay, 2000). In terms of Rostol's theory, the share of consumption should rise as the country grows from its economic taking off to the dimensional consumption period, thus a decreasing share of savings. But it seems quite another story with the growth experience in China. This paper provides another aspect that can serve as a rationale for the halted even decreased consumption shares in China, which is consistent with salient features of the "New Normal" experience in China. The sustained high savings rate can be attributed to the expansion of governmental expenditures. In terms of macroeconomic theories, long term expansion of governmental purchase will crowd out individual consumption and prevent the economy from its taking off to the period of dimensional consumption, thus deterring the savings rate to decrease and the increase of the volume of import. In this aspect, it is obvious to understand why China has accumulated such a big stock of foreign reserves.

This paper also provides a different point of view with some of the literature arguing that the appreciation of RMB should be conducted. Their rationales are attributed to the huge stock of foreign reserves [30] (Yang et al, 2013) and the relevant increasing managerial cost, low level of consumption [27] (Tilford, 2009), excessive capacity in infrastructure-related sectors while lack of a decent dimension of service sector [33] (Zyurt, 2013), high level of inflation [6] (Davies, 2014) and over hitting in real estate, and serious environmental pollution (Tilford, 2009). But these are not caused by the fixed level of exchange rate: as price can fluctuate, the real exchange rate 
can adjust though holding the nominal exchange rate constant. The key difference is that price adjustment is a gradual process, it can adapt to the economic change step by step, and thus the adjustment process is a "soft landing". However, if the nominal exchange rate is adjusted directly, the effect is instant and there is no time for firms to adjust their production methods or to switch to other fields. The economy is on a process of "hard landing". Actually, the policy recommendation can be given as the following: a reform should be conducted in the governmental sector to reduce its expansion in expenditures, which can enhance consumption and reduce current account surplus. Direct adjustment of the nominal exchange rate can only result in the slowdown of growth rate and TFP progress, low level of inflation and unemployment, decreasing returns on capital investment, extensive reallocation among agriculture, manufacturing and modern service sectors, rising share of consumption, improvement of wealth distribution, and reduced foreign surplus and trade volume. This is just the "New Normal" in recent China's growth experience.

\subsection{Innovative Points and Structure of the Paper}

The combination of slowdown of TFP progress, on the one hand, and reduced trade volume, on the other hand, is "puzzling". In terms of international economic theories: appreciation of domestic currency can drive inefficient firms out of market, thus promoting the TFP progress; Moreover, though exports growth falls as the process of appreciation, imports, on the contrary, should rise in terms of an increasingly larger purchasing power of domestic currency, thus the effect of appreciation to trade volume is ambiguous. The first innovative point of this paper is the explanation to the paradox above.

This paper proposes a theory of wage rigidity and asymmetric technology diffusion as the rationale for this puzzling phenomenon. According to the theory, both the slowdown of TFP progress and the reduced trade volume are resulted from wage rigidity, asymmetric technology diffusion and subsequently the reallocation of resources among agriculture, manufacturing and modern service sectors. With the appreciation of RMB and wage rigidity, FDI firms specializing in processing on order in the manufacturing sectors, face a swelling cost of labor. As incumbent FDI firms exit the manufacturing sector, not only export growth but also the imports of intermediate materials have decreased, thus a reduced trade volume. As is shown in figure 2, since 2007, both China's import volume and export volume have shared a same tendency of slowdown in long-term growth rate. The post-2015 data shows that both the growth rate of import volume and export volume have turned negative, thus a negative value for the growth rate of entire trade volume. In addition, appreciation of RMB also deters the potentially new entrants to invest in the manufacturing sectors including FDI firms with a continuum higher technology transfer, thus holding back the TFP progress.

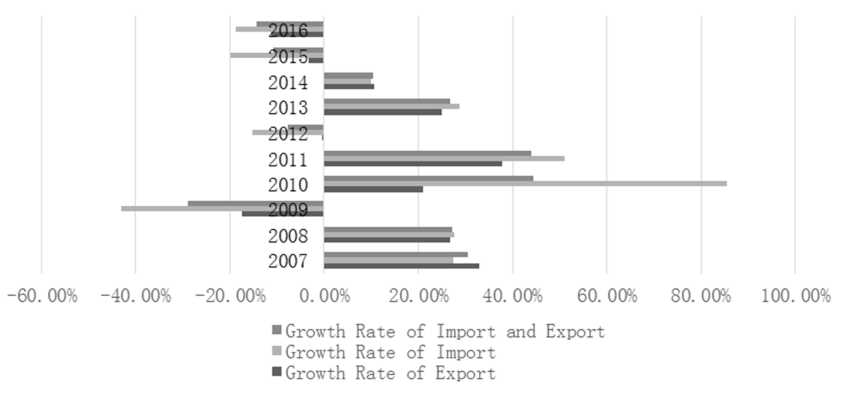

Data Source: Ministry of Commerce People's Republic of China.

Figure 2. Time Tendency of China's Import and Export Volume.

The second innovative point can be attributed to the dynamic methodology adopted by this paper compared to the static view adopted by the majority of the current literatures. Different from the current literature, this paper embarks from the dynamic view and tries to find whether the accumulative change of variables of ex ante or ex post period of the "New Normal" phase in China, which can exert the phenomenon reconciling the "New Normal" experience. The finding of this paper is that the direct reason for China's entering of the phase of "New Normal" is attributed to the long-term decrease of technological diffusion from FDI firms and the exacerbating accumulation of nominal wage rigidity in the labor market. Hence, this paper opens the black box of the reason for China's entering of the phase of "New Normal". The theoretical model proposed in this paper derives equilibrium consistent to the "New Normal" experience in China.

The third innovative point in this paper is that this paper gives different policy recommendations compared to other papers. Some papers contend that the phase of "New Normal" in China is resulted from China's direct economic structural transition and China's way out from the "New Normal" is also inevitably through the direct economic structural transition. This paper adopts a dynamic view and opens the black box for the reason of China's entering the phase of "New Normal". The finding of this paper is that the direct reason for China's entering of the phase of "New Normal" is attributed to the long-term decrease of technological diffusion from FDI firms and the exacerbating accumulation of nominal wage rigidity in the labor market. The two reasons above invoked a positive feedback effect under the shock of exchange rate reform in 2005, deteriorating the potential of China's TFP growth, which is leading China's entering of "New Normal" step by step. Without foreseeable changes, China's economy will trap into the phase of "New Normal" with larger depth. Therefore, this paper provides policy recommendations as "reversed manipulation", i.e., to adopt policy manipulation which has opposite effect compared with the exchange rate reform in 2005. This kind of manipulation needs not to be narrowed within the scope of exchange rate but any other manipulation that might offset the negative shock to international trade by exchange rate reform, thus promoting the competitiveness of a country in terms of cross-country trade.

This paper is organized as follows: Section 2 describes some empirical evidence of China since 2005. Section 3 describes the theoretical model and characterizes equilibrium. 
Section 4 checks the causal relationship between trade volume and the TFP progress in China and discusses the results. Section 5 concludes.

\subsection{Deficiency in This Paper and Possible Improvements}

There exist some assumptions aiming to simplify the analysis of the theoretical model. All these assumptions will be relaxed in the future research. First and foremost, this paper does not endogenize the deterministic form of the coefficient describing the level of technological diffusion from FDI firms, only to consider it as an exogenous coefficient. Second, this paper largely attributes the nominal wage rigidity in the labor market to the governmental regulation. However, there definitely exist other frictional factors which can be considered and incorporated into the deterministic mechanism of the nominal wage rigidity in the labor market. Third, an economic growth theory with the introduction of both infrastructure construction and human capital accumulation can be a better depiction of the "New Normal" experience in China.

\section{The "New Normal" in China: Empirical Evidence}

\subsection{Economic Reforms and Macroeconomic Trends}

China introduced its economic reform on exchange rate on July $21^{\text {st }}, 2005$. According to the People's Bank of China Announcement No. 16 [2005], the RMB exchange rate is no longer being pegged to the U.S. dollar since July $21^{\text {st }}, 2005$. It switches to a more flexible RMB exchange rate mechanism, practices on the basis of market supply and demand with reference to a basket of foreign currencies, and performs as a managed floating exchange rate system (The People's Bank of China, 2005). The reform first established a corridor within which the exchange rate can fluctuate in terms of demand and supply in the foreign exchange market. While when the exchange rate goes out of the corridor, governmental intervention is needed to keep it back within the corridor. This, if not devastating, incurred a substantially profound shock to the Chinese economy. Combined with the wage rigidity in the labor market, as a result, the share of manufacturing sector, which is mainly led by processing on order, shrunk decently and thus the trade volume. Moreover, in the manufacturing sector, incumbent domestic firms exit and incumbent FDI firms switch to other host countries, say, Vietnam, due to the rising cost in their labor expenditure. After two years, China abolished the super-preferential treatment towards FDI firms and levy more taxes on them in the context of citizen treatment. This conduct not only failed to internalize the positive externality from FDI firms, say, a continuum of technology diffusion, but also harmed the profitability of incumbent FDI firms and potential entrants.

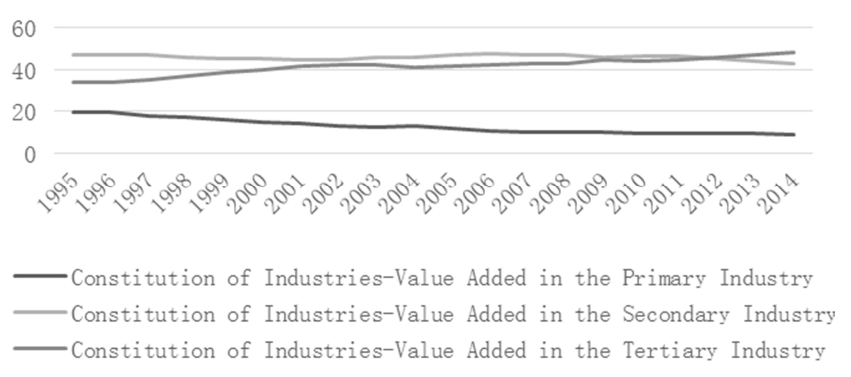

Data Source: National Bureau of Statistics of China.

Figure 3. Constitution of Industries: 1995-2014.

In addition, with the exit of existing firms and failure to further attract "Green Field Investment", unemployment rises in manufacturing sector. As is shown from figure 3, the recent 20 years have witnessed tremendous changes in the constitution of industrial structure in China. Conceivably, the share of agriculture sector decreases from nearly $20 \%$ in the late $20^{\text {th }}$ century to just $10 \%$ in 2014 ; the share of the secondary and tertiary industries keeps rising. In 2013, the share of the secondary industries was first surpassed by the share of the tertiary industry.

In order to clear the labor market, the Chinese government then launched a series of measures to subsidize the agriculture sector and increase infrastructure investment. Consequently, what was observed was a process of counter-urbanization and thus the inverse migration of residents from urban areas back to rural areas, as well as an excessive capacity in the infrastructure and its forwards and backwards related industries, say, steel, iron, cement and concrete. Since the $3^{\text {rd }}$ Plenary Session of 18th CPC Central Committee on November $9^{\text {th }} 2013$, China officially endorsed a decisive role of private firms in the economy with a dwindled dimension of governmental activities, a reduced level of taxation towards small and medium-sized enterprises (SMEs), a less sophisticated procedure for firm registration and an increased openness to private firms among more sectors. These economic reforms enhanced the role of private firms in the society, but with the retreat of FDI firms in the manufacturing sector, China failed to rejoin the international labor division system.

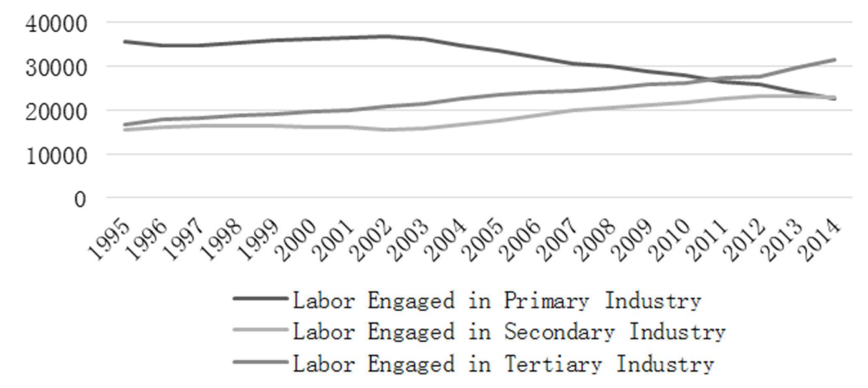

Data Source: National Bureau of Statistics of China.

Figure 4. Labor Distribution Among the Three Industries: 1995-2014.

What this paper observes is a labor transfer from the manufacturing sector to agriculture and modern service sector. As is shown from figure 4, with time passing by, China's labor 
distribution changes significantly among industries. The labor engaged in agriculture activities decreases sharply in the last 20 years with the main reason of urbanization; the labor engaged in the secondary and tertiary industries keeps rising with the fact that the growth rate of labor engaged in the tertiary industry exceeds significantly to the growth rate of labor engaged in the secondary industry. Therefore, this paper observes the expanding gap between the labor engaged in secondary and tertiary industries. This phenomenon is attributed to the acceleration of growth of the secondary industry, which has stimulated the increase in demand of the tertiary industry. De facto, the explanation above contributes to the understanding of the reason that after China's entering of the phase of "New Normal", with manufacturing sector continuously releasing unemployed labor, it is, on the contrary, hard to observe a significant increase in unemployment. This is because there exists a reallocation of labor among the agriculture sector, modern service sector, and the manufacturing sector. Due to the fact that TFP growth in the tertiary industry is very sluggish, the demand increase is nearly fully reflected by the increase in employment in the tertiary industry. The tertiary industry itself is capable of absorbing the large number of unemployed population from the manufacturing sector. The sluggish attribute of growth in TFP in the service sector makes itself more capable to accumulate working population.

The focus of this paper is on the post-2005 Chinese economic transition, a period characterized by slowdown of growth and profound resource reallocation among manufacturing, agriculture and modern service sectors. Instead of an average of two-digit growth rate, China's economic growth has slowed down from $10.6 \%$ in 2010 to $7.4 \%$ in 2014 . From figure 5, both the index of GDP and the index of GDP per capita reached their peaks in 2007. Since 2007, the two indices have kept decreasing. Before 2007, the two indices were rising continuously. Through the observation of space between the two curves, this paper finds that the population growth in China is slowing down, and the aging in population is exacerbating.

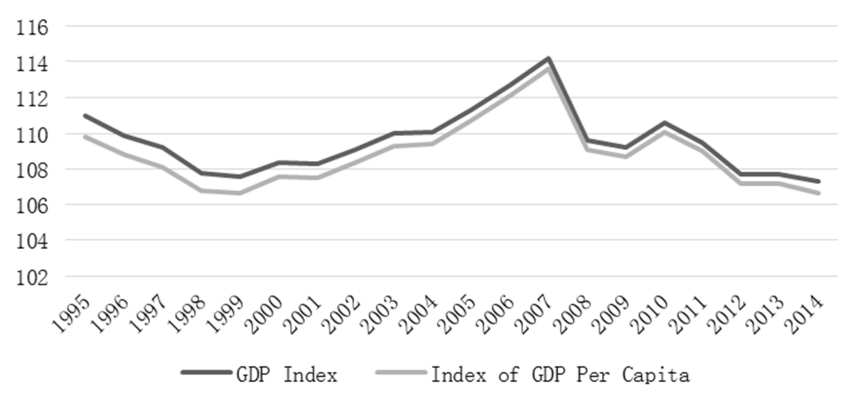

Data Source: National Bureau of Statistics of China.

Figure 5. GDP Index and Index of GDP Per Capita.

At the same time, figure 5 shows a low level of unemployment rate and inflation pressure: On the one hand, in 2014, the newly increased employed people in urban areas reached 13.22 million. The registered urban unemployment rate was 4.09 percent at the end of the year; On the other hand, the year-on-year inflation rate, measured by CPI (Consumer Price Index), dropped to $1.5 \%$ at the end of 2014 , while the month-on-month inflation rate stagnated, more or less at the level of $0.3 \%$.

In addition, the growth rate of investment was rather sluggish: total investment in fixed assets of the country in 2014 was $51,276.1$ billion Yuan, up by 15.3 percent over the previous year. The real growth was 14.7 percent after deducting the price factors. However, not only the growth of investment in fixed assets slowed down, but also with the rebalancing of investment in two categories. Firstly, investment is rebalancing among regions: of the total investment, the investment in fixed assets (excluding rural households) was 50,200.5 billion yuan, up by 15.7 percent, the investment in eastern areas was 20,645.4billion yuan, up by 15.4 percent over the previous year, in central areas was $12,411.2$ billion yuan, a growth of 17.6 percent, in western areas $12,917.1$ billion yuan, a growth of 17.2 percent, and in northeastern areas 4,609.6 billion yuan, up by 2.7 percent. Secondly, it also shows a reallocation of investment among industries: concerning with investment in fixed assets (excluding rural households), the investment in the primary industry was $1,198.3$ billion yuan, up by 33.9 percent; that in the secondary industry was $20,810.7$ billion yuan, up by 13.2 percent; and that in the tertiary industry was $28,191.5$ billion yuan, up by 16.8 percent.

Moreover, the corporate returns have now gradually been matched by the return on financial assets available to individual depositors, due to the rise of China's shadow banking.

Finally, income growth has exceeded the growth in output per capita in recent years: the income of urban and rural residents continued to rise. In 2014, the national per capita disposable income was 20,167 yuan, an increase of 10.1 percent or a real increase of 8.0 percent after deducting price factors. In terms of permanent residence, the per capita disposable income of urban households was 28,844 yuan, up by 9.0 percent, or a real growth of 6.8 percent after deducting price factors. The per capita disposable income of rural residents was 10,489 yuan, up by 11.2 percent, or 9.2 percent in real terms.

\subsection{Reallocation Among Agriculture, Manufacturing and Modern Service Sectors}

The reallocation of capital and labor among the agriculture, manufacturing and modern service sectors is the focal point of my theory. Firstly, a reallocation of investment among industries is as follows: concerning with investment in fixed assets (excluding rural households), the investment in the primary industry was $1,198.3$ billion yuan, up by 33.9 percent; that in the secondary industry was $20,810.7$ billion yuan, up by 13.2 percent; and that in the tertiary industry was $28,191.5$ billion yuan, up by 16.8 percent. Secondly, both employment and output of the manufacturing sector as a share of the national total began to decline in 2013, with manufacturing output smaller than service output for the first time. In the first half of 2014, services accounted for more than half of the country's growth [32] (Yang Yao, 2013). As is seen from figure 6, the industrial constitution of China in 2014 is respectively $9.2 \%$ in primary industry, $42.7 \%$ in secondary industry, and $48.1 \%$ in tertiary 
industry. Nearly half of the value added of the entire economy is contributed by the tertiary industry.

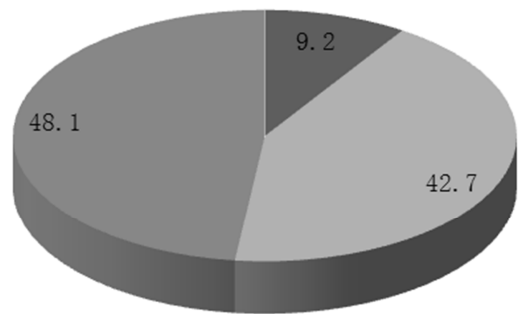

- Constitution of Industries-Value Added in Primary Industry(\%)

- Constitution of Industries-Value Added in Secondary Industry (\%) - Constitution of Industries-Value Added in Tertiary Industry (\%)

Data Source: National Bureau of Statistics of China.

Figure 6. China's Constitution of Industries in 2014.

\subsection{Technology Diffusion, Productivity and Wage Rigidity}

Manufacturing sector differs from modern service sector in productivity: the progress of productivity of labors in manufacturing sector is more rapid than that of modern service sector due to learning-by-doing effect and technology diffusion from FDI firms. With the exit of incumbent FDI firms and deterring of potentially new entrants of FDI firms with higher technology level, the technology diffusion gradually slowed down.

The slowdown in technology diffusion invoked at the same time the slowdown of the growth of labor productivity. In order to cope with the external source of TFP growth, policy orientation emerged in order to strengthen self-innovation. As a result, expenditures on research and development activities (R\&D) were worth of 1,331.2 billion yuan in 2014, up by 12.4 percent over 2013, which suffers a relative drop from a growth rate of $21.7 \%$ in 2010 .

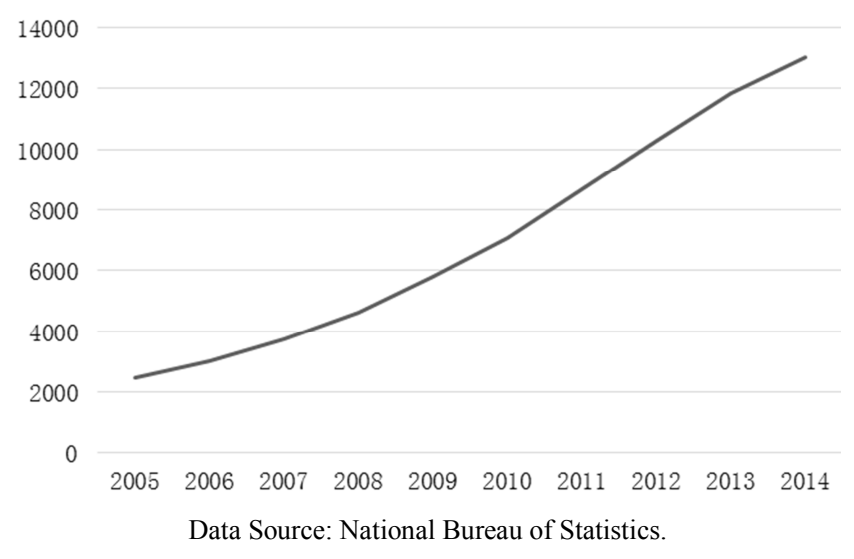

Figure 7. China's R\&D Expenditure: 2005-2014.

As is shown from Figure 7, since 2005, China's R\&D expenditure has been in a rising tendency. Figure 7 points out that China's R\&D expenditure has increased from 200 billion in 2005 to 1.3 trillion in 2014, a nearly six-time magnitude of increase.

At the same time, although it can be seen that China's R\&D expenditure has been increasing, this trend is approaching its turning point. Compared to the rate of growth of China's R\&D expenditure from 2005 to 2009, in the years between 2009 and 2014 , the growth rate of R\&D expenditure in China has been mitigating. This phenomenon can be well depicted by Figure 8 . As is shown from Figure 8, the year 2009 is the turning point in terms of the growth rate of China's R\&D expenditure. Before 2009, the growth rate of China's R\&D expenditure was in an increasing interval with a high level of $20 \%$ increase per annum. The R\&D expenditure serves as the premise and basis for a country to maintain its high domestic technological progress, and promote its labor productivity. It is due to China's rapid increase in terms of $R \& D$ expenditure that in the past years, China succeeded to promote its TFP growth even exerting convergence towards the developed countries. However, from Figure 8, it is also obvious that since 2009, the growth rate of China's R\&D expenditure suffered a significant and continuous drop. In 2009, the growth rate of China's R\&D expenditure reached the level of $26 \%$. Nevertheless, in 2014, the growth rate of China's $R \& D$ expenditure decreased to merely $10 \%$, which would undoubtedly prolong China's catching up with the developed nations via its promotion of TFP growth.

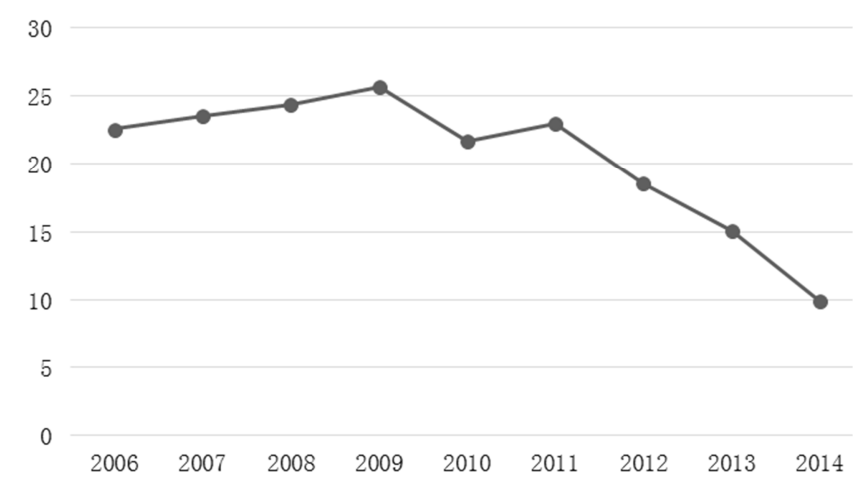

Data Source: National Bureau of Statisitics of China.

Figure 8. The Growth Rate of China's R\&D Expenditure: 2006-2014.

The phenomenon above seems ambivalent: why the moves adopted under the propaganda to strengthen domestic innovation invoked exactly the counterproductive result that the level of domestic innovation even decreased. This paper constructs a theoretical model in section 3 , which can provide the paradox with a reasonable explanation: with the rising level of cost of labor, FDI firms agglomerating in the field of processing on order economy will exit from the manufacturing sector gradually. With this trend going on, the domestic firms with forward and backward linkage with FDI firms will suffer from a decreasing level of technological diffusion, thus lowering the necessary $\mathrm{R} \& \mathrm{D}$ expenditure to succeed in indigenizing the technological diffusion from FDI firms.

Wage rigidities are not unexpected in China, where the labor market is more regulated than in other developing countries. More recently, in an apparent attempt to stem the contraction in private consumption, the government has raised the wages of public sector workers and the minimum wage of all workers [28] (Rod Tyres, 2000). 


\subsection{Income Inequality and Share of Consumption}

The rebalancing since 2005 has contributed to China's improvement in her income distribution. Growth slowdown is unevenly distributed across the country; it mostly occurs in the coastal provinces that produce more than 85 percentage points of China's exports. Inland provinces have maintained relatively high growth rates, thus creating convergence within the country. As a result, the national Gini coefficient of personal income declined from 0.481 in 2010 to 0.473 in 2013 (Yang Yao, 2013).

This is consistent with the model's prediction: with the exit of incumbent FDI firms and deterring of potentially new entrants of FDI firms with higher level of technology, growth in coastal cities slowed down, while due to governmental policy support in the inland regions, growth has been highly sustained. The reversal in growth rate between inland regions and coastal regions contributed to the improved condition of equality of income distribution.

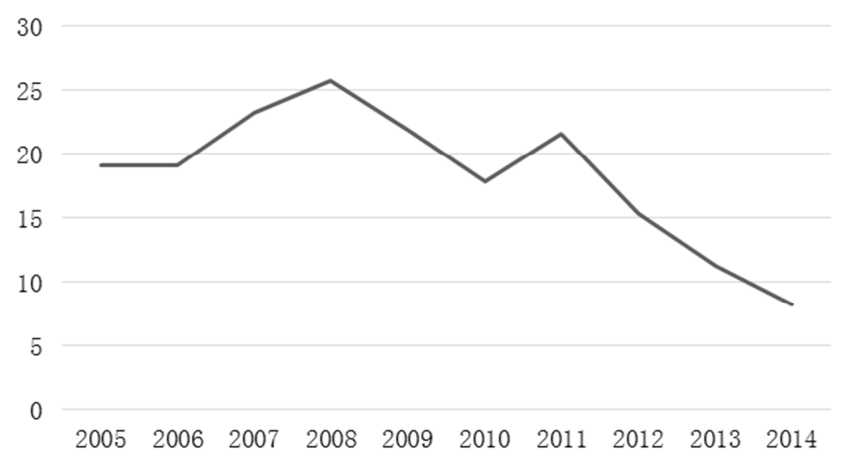

Data Source: National Bureau of Statistics of China.

Figure 9. The Growth Rate of China's Governmental Expenditure: 2005-2014.

With the redistribution of income and dwindling of the governmental purchasing, domestic consumption as a share of GDP stabilized in 2008 and finally began to rise in 2013 (Yang Yao, 2013). From Figure 9, the growth rate of China's governmental expenditure keeps decreasing in recent years. From 2005 to 2008 , the fiscal expenditure was rapidly increasing, reaching its peak in 2008 with the growth rate of $26 \%$. In the following years, the fiscal expenditure has been decreasing. In 2014, the growth rate of fiscal expenditure decreased to $8 \%$. Considering the fact that the stable decrease in the governmental expenditure for a relatively long period will cast some influence on consumers with forward horizon to recalculate their permanent income level, in the view of a representative consumer, the stable decrease in the growth rate of governmental expenditure from Figure 9 will definitely increase his lifetime permanent income. Considering the fact that the consumer has forward horizon toward consumption, he has the incentive to smooth the incremental permanent income over his entire lifetime. Therefore, what should be observed is the rising share of consumption in the demand constitution of the current state.

Figure 10 can be a good description of China's rising tendency of consumption share in recent years. As is shown from Figure 10, China's final consumption expenditure's contribution to the growth of the entire economy remained low from 2005 to 2008 . However, with the slowdown of the growth rate of the governmental expenditure, the consumers begin to expect an increase in their permanent income and therefore increase their consumption level. Hence, a reflection of the facts above is the rising percentage points of consumption to income from 2009 to 2014, which remained at a relatively high level compared to that from 2005 to 2008 .

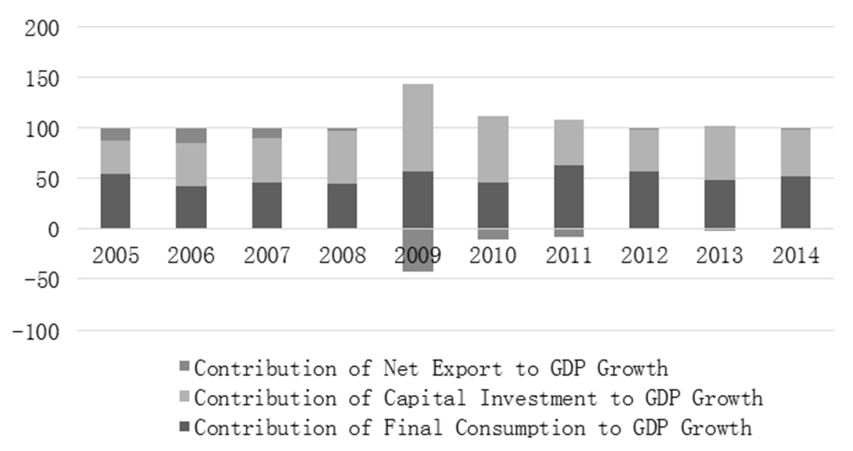

Data Source: National Bureau of Statistics of China.

Figure 10. Contribution of Final Consumption to GDP Growth in China: 2005-2014.

\subsection{Trade Volume, Foreign Surplus and Productivity Growth}

Export growth has substantially slowed down, from an average of 29 percent per annum between 2001 and 2008 to less than 10 percent per annum in recent years. As a result, exports have become less important for the country's growth, to the point that the contribution of net exports has become negligible, if not negative, while the indirect contribution of exports through forward and backward linkages has also shrunk. Consequently, the overall contribution of exports to growth has declined from 3 percentage points to about 1 percentage point (Yang Yao, 2013). The size of China's current account surplus has shrunk quickly, accounting for about 2 percent of GDP in recent years. Concerning to the major role of processing on order in manufacturing sector and the technology diffusion from FDI firms, the reduced growth rate of trade volume is very likely to result in a slowdown of growth rate in total factor productivity, which is quite consistent with the implication of the model in section 3 .

The interconnection between the slowdown of the growth rate of export volume and the slowdown of the growth rate of the entire volume of trade can be well illustrated by Figure 11. As is shown from Figure 11, first, China's growth rate of import volume, export volume, and the entire volume of trade, shares the exactly same time tendency, with transient increase between years from 2001 to 2003, and a significant decrease tendency between the years from 2003 to 2009. In 2010, the trade sector of China enjoyed a significant increase, with its growth rate even back to its highest level of $40 \%$ in 2003 . However, so far until 2014, China's growth rate of import volume, export volume, and the entire volume of trade, has decreased to the level lower than $5 \%$. The explanation to this phenomenon follows exactly the logic in this paper above that 
the pattern of production in China's trade sector, a processing on order fashion, determines the potential strong endogenous relationship between China's import volume and export volume. In this extension, the change of growth rate of import volume will exert the influence to that of export volume in the same direction at the same magnitude. It is also true of the conflated influence on the growth rate of the entire volume of trade, because the growth rate of the entire volume of trade equals exactly to that of the weighed summation of the growth rate of export volume and import volume.

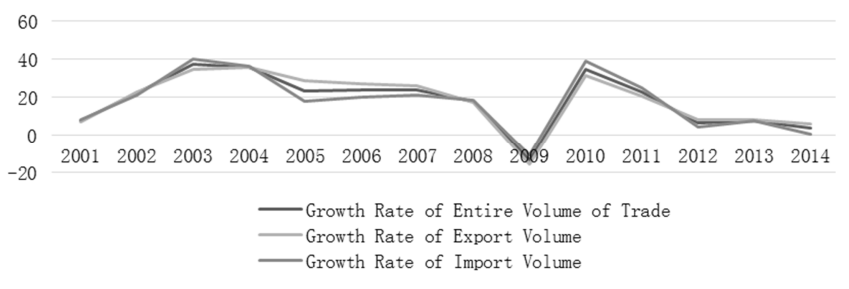

Data Source: National Bureau of Statistics of China.

Figure 11. The Growth Rate of China's Export and Import Volume: 2001-2014.

\section{The Benchmark Model}

This section is based on a theory of economic growth consistent with the empirical facts documented in the previous sections.

\subsection{Preferences, Technology and Markets}

\subsubsection{Preferences and Demographics}

Suppose the case is in an infinite-horizon economy in continuous time, a household with the following preference is considered as a typical representative, with the weight assigned in terms of different share of labors among industries.

$$
\sum_{i=1}^{3} \omega_{i} \cdot \int_{0}^{\infty} \exp \left(-\rho_{i} t\right) \cdot \frac{C(t)^{1-\theta}-1}{1-\theta} d t
$$

where $\rho$ is the time preference parameter, $i=1,2,3$ representing respectively the domestic manufacturing sector, modern service sector, and the agriculture sector, and suppose that $\rho_{i}$ suffices the following condition: $\rho_{1}=\rho_{2}>\rho_{3} ; \theta$ is the inter-temporal elasticity of substitution in consumption $\mathrm{C}(\mathrm{t})$. We focus on the case when agents' savings are non-decreasing in the rate of return, i.e., when $\theta \leq 1 ; \omega_{i}$ refers to the share of labors in sector $i$.

Suppose the population that works in the domestic manufacturing sector which does not have any forward and backward linkage with FDI firms, faces no population growth, and the total population of workers in the domestic manufacturing sector, $L_{M}$, supplies labor with poor elasticity. $L_{M}$ suffices the following condition: $L_{M}=L_{F}+L_{I}$, with $L_{F}$ as the aggregate labor input of the final good producers in domestic manufacturing sector, and $L_{I}$ as the aggregate labor input of the intermediate good producers in domestic manufacturing sector. The total labors working in modern service sector and agriculture sector are respectively $L_{A}$ and $L_{S}$.

\subsubsection{Technology and Market}

There are two kinds of firms in the domestic manufacturing sector: the final goods producer and the intermediate goods producer.

The unique final good is produced in a competitive market with the following production function

$$
Y(t)_{M}=\frac{1}{1-\beta}\left(\int_{0}^{N(t)} x(v, t)^{1-\beta} \cdot d v\right) \cdot L_{F}^{\beta}
$$

Where $L_{F}$ is the aggregate labor input in the final good producing firms, $\mathrm{N}(\mathrm{t})$ denotes the number of various intermediate inputs available to be used in the production process at time $\mathrm{t}$, and $\mathrm{x}(v, \mathrm{t})$ is the total amount of input of variety $v$ used at time $\mathrm{t}$. Assume that $\mathrm{x}$ depreciates fully after use; thus they can be interpreted as generic inputs, semi-manufactures, or even disposable capital provided by an intermediate good producing firms, as long as we are convinced by the assumption that there is immediate depreciation. The term $(1-\beta)$ in the denominator is included for notational simplicity. Notice that for a given $N(t)$, which is exogenous to final good producers, (2) exhibits constant returns to scale. This formulation is rather realistic: since the varieties of intermediate goods are fixed, as long as firms are able to duplicate its former dimension of production, it manages to double output.

Now switch to the settings of how machines are produced and how new machines are invented. Assume that once the blueprint for a certain machine variety is invented, one unit of that machine can be produced at marginal cost equal to $\psi>0$ units of the final good. Here presents the simplest version of the endogenous technological change model with knowledge spillovers. The innovation possibilities frontier takes the form

$$
\dot{N}(t)=\eta N(t) L_{I}(t)
$$

where $L_{I}(t)$ is labor allocated to intermediate good producing firms at time $t$. The term $\mathrm{N}(\mathrm{t})$, on the right-hand side, captures spillover effect from the stock of existing ideas. This implies that the current innovators are standing on the shoulder of the giant. The greater is $\mathrm{N}(\mathrm{t})$, the higher productivity a worker owns in the intermediate good producing firm. $\eta$, which is bigger than 0 , is the coefficient describing the technology diffusion from the FDI firms. Those FDI firms, establishing their subsidiaries, are largely motivated by the intrinsic different factor endowment in the host country. For example, since China once has a huge amount of labor force supplied elastically. There exists an incentive for FDI firms to transfer some of their product chain and thus the relevant technology in China in order to arbitrage the cheap price of labor force. Consequently, since the public goods feature of knowledge, advanced technology can diffuse from FDI firms to domestic manufacturing intermediate firms via the process of imitation and learning by doing. The more attractive a host country to FDI firms is, thus the larger incumbent number of FDI firms and the potential entrants will be; the bigger the technology diffusion is, the bigger coefficient $\eta$ will be.

Suppose that the initial technology stock is $N(0)>0$. Equation (3) implies that larger number of workers located in 
the intermediate goods producing firms can lead to a faster pace of innovation on new machines. Throughout the assumption that there is no barrier for entry into research in the intermediate goods firms, which means that any individual or firm can hire one unit of workers at time $t$ to generate a flow $\eta N(t)$ of new blueprints. The firm that conceives a blueprint for a new machine receives a fully guaranteed perpetual patent on this machine variety. Moreover, suppose that the $\mathrm{N}(0)$ initial varieties are also supplied by monopolists with perpetual patents.

Given the specification of patent structure as above, a firm that invents a new machine variety $v$ is the monopolistic supplier of that machine variety and sets a price of $p^{x}(v, t)$ at time $t$ to maximize profits.

Suppose the production functions of the agriculture sector and the modern service sector are respectively $Y_{A}=L_{A}$ and $Y_{S}=A_{S} \cdot L_{S}$, with the fact that there exists asymmetric technology diffusion among various sectors. Suppose the TFP growth rate of the modern service sector is less than that of the domestic manufacturing sector, i.e.,

$$
\frac{\dot{A_{S}}}{A_{S}}<\frac{1}{\theta} \cdot\left((1-\beta) \eta L_{F}^{*}-\rho_{1}\right)
$$

\subsection{Discussion of Assumptions}

Before arriving at the equilibrium state, it is very important to discuss the validity for some of the key assumptions made above.

The assumption that the representative household has a CRRA lifetime utility function is quite reasonable because any rational household must have an incentive to smooth their consumption among different periods, thanks to the decreasing marginal utility and the trade-off between the time-discount coefficient $\rho$ and the interest rate r. Moreover, since Chinese parents are very concerned with the welfare of their offspring, and they tend to consider not only the consumption of their own lives but also the consumption of their descendent, an infinite-horizon model is used to capture this typical feature.

The assumption regarding the difference of time preference coefficient among the agriculture sector, modern service sector, and the domestic manufacturing sector is valid description to China. This is because the duality of market in China is still an obvious characteristic. Hence, there exists large difference of time preference coefficient between urban and rural residents. To be more specific, rural residents in China are usually more patient than urban residents. For lack of sufficient social welfare and rich financial investment channels, rural residents are inclined to save a large portion of their revenue in case of exigent expense in the future. Therefore, their time preference coefficient is less than that of the urban residents, i.e., smaller value of $\rho$.

The demography assumption for a constant population in the domestic manufacturing sector is also deeply rooted in the Chinese experience. Taking into consideration the facts that workers in the domestic manufacturing sectors are generally innovative because in this sector, the engine for continuous growth is a continuum of innovations conducted in the sector endogenously. Thus, the stock of knowledge, captured by $\mathrm{N}(\mathrm{t})$ in the innovation possibilities frontier, is crucial for the innovation of new intermediate goods and thus the innovative labor force. The current constant population in the domestic manufacturing sector can be a balance between "pushing" and "pulling" forces. On the one hand, the "pushing" force for the increase of the innovative labor force is expansion of the school enrollment among Chinese universities since 1999. As is shown from Figure 12, China's higher education indeed assumes significant expansion in scale over the past decade. The expansion in scale of China's higher education was, particularly, focused on the primary period of higher education. It can be seen from Figure 12 that the distinctive characteristic lies in that the number of students of undergraduate study period rose earlier than that of postgraduate and doctoral students, and the number itself was also larger. The expansion in scale of higher education can be disseminated into two different mechanisms: first, the incumbent higher education institutes expanded their owed student scale; second, more newly established higher education institute participated in the process of expansion of student scale from 1999.

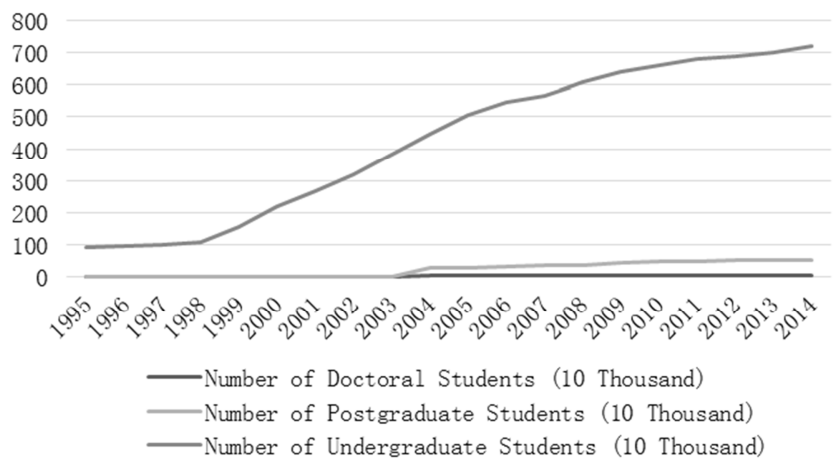

Data Source: National Bureau of Statistics of China.

Figure 12. China's Scale of Higher Education.

Due to the expanded number of students to be enrolled in universities, an increasing number of population gained access to receive higher education and thus becomes educated. But still one problem needs to be considered. With the expansion of student enrollment and a relatively shrunk level of teaching resources, especially the care from the teachers, whether the expansion has contributed to the rising number of innovative people has to be questioned; On the other hand, the "pulling" force for the decrease of the innovative labor force is the turning point of labor participation. The country's working-age ratio reached its peak of 2.6 in 2010 and has since begun to decline. In fact, the absolute number of working-age population began to decline in 2012. This is largely due to the "Family Planning" policy, which is also known as the "One-Child" policy, in China since the 1980 s. After a generation of more than 20 years, the elderly generation retires and exits the labor force when the first generation under "One-Child" policy enters. For the number of population in the former (generation of baby boom in China) is quite larger than that in the latter, 
innovative workers tend to dwindle. Consequently, the balance between the two forces maintains a constant number of workers in the domestic manufacturing sector. As is shown from Figure 13, since the reform in higher education in 1999, China's labor distribution among the three industries has the following characteristics: first, with the process of urbanization, labors engaged in the agricultural activities decrease sharply; second, labors engaged in the tertiary industry enjoy a more rapid increase even than that of the entire employment, specifically as is depicted in Figure 13 , the time tendency line representing the tertiary industry has a steeper slope than that of the national employment; third, labors engaged in the secondary industry also enjoy a rising tendency while its growth rate is slower than that of the tertiary industry and that of the entire employment.

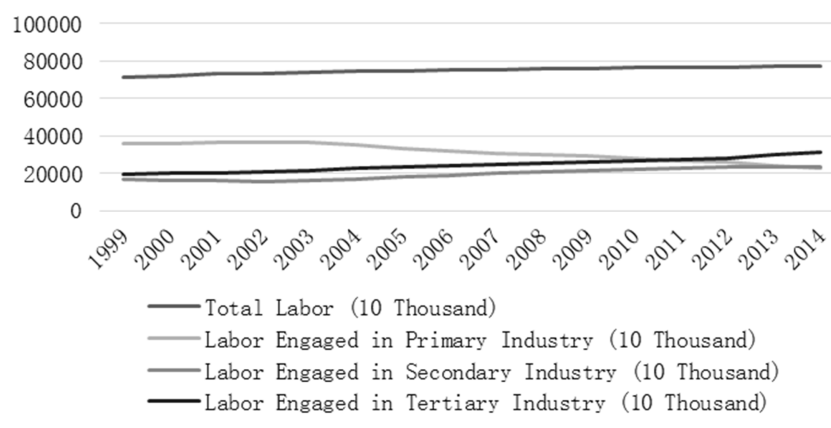

Data Source: National Bureau of Statistics of China.

Figure 13. Time Tendency of China's Labor Distribution Among Industries: 1999-2014.

The assumption of the innovative possibilities frontier is well depicted by equation (3). Coefficient $\eta$, capturing the technology diffusion of FDI firms, is a proper description of Chinese experience, since the innovation in domestic manufacturing sector in China enjoys largely positive externalities from FDI firms. Through bilateral communication and cooperation, the advanced managerial approaches, operational experiences, and even state-of-the-art technology, have flowed from the FDI firms to domestic manufacturing sector via the process of imitation and learning by doing, which enhances the domestic innovation process a lot.

The assumption that a firm, inventing a new machine variety $v$, is the sole (monopolist) supplier of that machine variety and sets a price of $p^{x}(v, t)$ at time to maximize profits is also an approximate description of the Chinese experience. Especially in recent years, with a stronger awareness of copyright protection, many innovation firms hold patents and gain a substantial degree of market powers, such as Tencent, a social-network-service company in China. As can be seen from Figure 14, with China's strengthened measures to protect intellectual property rights and the enlarged input of $R \& D$ expenditure from individuals, enterprises, and the government, the number of domestic invention patents is increasing significantly. Since 2009, the growth rate of patent application has been accelerating. So far until 2014, the absolute number of patent application has risen up to five-time magnitude compared to that in 2005.

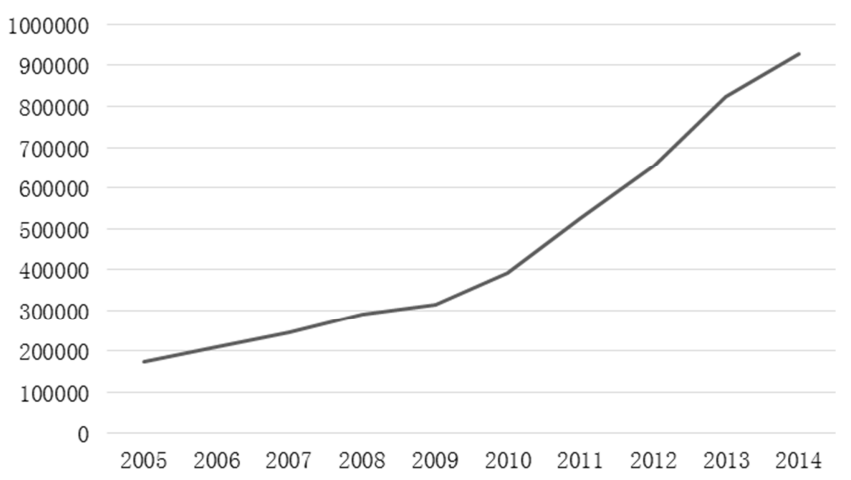

Data Source: National Bureau of Statistics of China.

Figure 14. China's Application of Invention Patents: 2005-2014.

\subsection{The Maximization Problem of the Final Goods Producer}

The demand for intermediate good variety $v$ is obtained by optimum of net aggregate profits of the final good sector. Since the disposable use of machines and availability to labor on the spot market without time lag, the solution to maximization problem of the final good sector can be obtained at each point in time independently and simply requires the maximization of the instantaneous profits of a representative final good producer. These instantaneous profits, by construction, can be obtained by subtracting the costs of intermediate good and labor from the value of production. Therefore, the maximization problem at time $t$ is

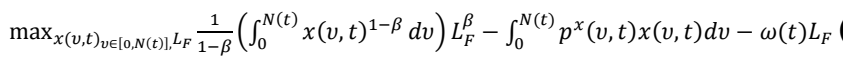

Demand for machines from the final good sector can be derived from the first-order condition of this maximization problem with respect to $\mathrm{x}(v, \mathrm{t})$ for any $v \in[0, \mathrm{~N}(\mathrm{t})]$, which takes the following convenient isoelastic form:

$$
x(v, t)=p^{x}(v, t)^{-1 / \beta} L_{F}
$$

Equation (5) implies that the demand for machines is only influenced by intermediate good cost and equilibrium labor supply in the final goods producing firms, but there doesn't seem to be a directly deterministic relation between demand for machines and the interest rate $\mathrm{r}(\mathrm{t})$, the wage rate $\omega(t)$, or the total measure of available machines $\mathrm{N}(\mathrm{t})$.

The first-order condition of maximizing (4) with respect to $L_{F}$ yields demand for labor from the final good sector and gives the equilibrium wage rate at time $\mathrm{t}$ as

$$
\omega(t)=\frac{\beta}{1-\beta} N(t)
$$

\subsection{Maximization Problem of the Intermediate Goods Producer}

Next consider the net present value (NPV) of the blueprint ownership of a machine of variety $v$. This value is given as the following

$$
V(v, t)=\int_{t}^{\infty} \exp \left(-\int_{t}^{s} r\left(s^{\prime}\right) d s^{\prime}\right) \pi(v, s) d s
$$


where

$$
\pi(v, t) \equiv p^{x}(v, t) x(v, t)-\psi x(v, t)
$$

is obtained by subtracting the manufacturing cost of intermediate good from the total revenue of sales and denotes the profits of the monopolist producing machine $v$ at time $t$ in the intermediate good producing sector, $x(v, t)$ and $P^{x}(v, t)$ are respectively the profit-maximizing choices for output and price of the monopolist, and $\mathrm{r}(\mathrm{t})$ is the market interest rate at time t. To put equation (7) in another way, assuming that the value function is differentiable with respect to time, (7) could be written in the form of a Hamilton-Jacobi-Bellman equation (HJB equation) as

$$
r(t) \cdot V(v, t)-\dot{V}(v, t)=\pi(v, t)
$$

From the firm side, since demands in (5) is well defined in the isoelastic form, the maximization problem of any monopolist $v \in[0, N(t)]$ yields setting identical price in every period:

$$
p^{x}(v, t)=\frac{\psi}{1-\beta} \text { for all } v \text { and } \mathrm{t}
$$

All monopolists thus enjoy a markup of $\frac{\beta}{1-\beta}$ over their marginal cost of production, $\psi$. Let us normalize the marginal cost of machine production to $\psi \equiv(1-\beta)$, so that

$$
p^{x}(v, t)=p^{x}=1 \text { for all } v \text { and } \mathrm{t}
$$

Profit-maximization also implies that each monopolist rents out the same quantity of machines in every period, equal to

$$
x(v, t)=L_{F} \text { for all } v \text { and } t
$$

This gives monopoly profits as

$$
\pi(v, t)=\beta L_{F} \text { for all } v \text { and } \mathrm{t}
$$

Equation (12) implies the symmetry of monopolists in the intermediate good sector. Each monopolist sells the same amount of machines, charges the same price, and makes the same amount of profits at all points in time.

Substituting (12) into (2) yields a derived production function for the final good:

$$
Y(t)_{M}=\frac{1}{1-\beta} \cdot N(t) \cdot L_{F}
$$

From the viewpoint of final good firms (which take $\mathrm{N}(\mathrm{t})$ as given), equation (14) shows that the aggregate production function exhibits constant returns to scale. However, there are increasing returns to scale for the entire economy. The reason for the occurrence of increasing returns to scale is due to the model setting in this paper that knowledge, as a new genre of production factor, is produced endogenously. With time passing by and input increasing, knowledge accumulates gradually. The channel for knowledge to influence the final output in the economic system is through promoting TFP growth rate. In addition, (14) implies that an increase in the variety of machines, $N(t)$, raises the marginal productivity of labor and that when $\mathrm{N}(\mathrm{t})$ increases at a constant rate so does output per capita.

\subsection{The Maximization Problem of Consumers}

Last but not the least, the representative household's maximization problem implies the Euler equation for optimal consumption,

$$
\frac{C(t)_{1}}{C(t)_{1}}=\frac{1}{\theta}\left(r(t)-\rho_{1}\right)
$$

and the transversality condition is as the following

$$
\lim _{t \rightarrow \infty}\left[\exp \left(-\int_{0}^{t} r(s) d s\right) \int_{0}^{N(t)} V(v, t) d v\right]=0
$$

It is written in the market value form and requires a binding budget constraint in order to maximize lifetime utility: the value of the total wealth of the representative household, which is precisely the value of corporate assets $\int_{0}^{N(t)} V(v, t) d v$, not to grow faster than the discount rate.

\subsection{The Free-Entry Condition and the Characteristics of the Equilibrium}

By construction of balanced growth path (BGP), consumption grows at a constant rate, say $g_{c}^{*}$. Equation (15) implies that a constant growth rate of consumption is possible as long as the interest rate is constant. Let us therefore look for an equilibrium allocation in which

$$
r(t)=r^{*} \text { for all } \mathrm{t}
$$

where the asterisk $(*)$ refers to equilibrium value on the BGP. Since equation (13) gives a constant profit at each date and the interest rate is also constant, (9) implies that $\dot{V}(t)=0$. Substituting this in (9), so obtains

$$
V^{*}=\frac{\beta L_{F}}{r^{*}}
$$

This equation is rather intuitive: the net present value of a blueprint for machine variety $v$ equals a flow profit of $\beta L_{F}$ discounted infinitely at the constant interest rate $r^{*}$ on the BGP.

Equation (3) implies the following free-entry condition:

$$
\eta N(t) V(v, t)=\omega(t)
$$

The left-hand side of (19), product of $\eta N(t)$ and $V(v, t)$, is the value of return from hiring one more worker for intermediate goods sector. $\eta N(t)$ is the incremental varieties of intermediate goods invented by one additional unit of labor input. $V(v, t)$, as defined above, is the NPV of owning a blueprint for machine variety $v$. The right-hand side is the cost of hiring one additional worker for intermediate goods, $\omega(t)$.

Substituting equations (6) and (18) into (19), the BGP requires that

$$
\eta N(t) \frac{\beta L_{F}}{r^{*}}=\frac{\beta}{1-\beta} N(t)
$$

Hence the BGP interest rate can be solved as the following

$$
r^{*}=(1-\beta) \eta L_{F}^{*}
$$


$L_{F}^{*}$ is the number of workers employed in the final goods sector in BGP (given by $L_{F}^{*}=L-L_{I}^{*}$ ). Since $r^{*}$ is constant on the BGP, equation (21) shows that the number of workers in the final good sector on the BGP must be constant. Now combining Euler equation of the representative household (15), so obtains

$$
\frac{C \dot{C(t)_{1}}}{C(t)_{1}}=\frac{1}{\theta}\left((1-\beta) \eta L_{F}^{*}-\rho_{1}\right)
$$

What follows is the determination of BGP level of employment, $L_{F}^{*}$, which completes the characterization of the BGP equilibrium. A variant of the innovation possibilities frontier, (3), implies $\frac{\dot{N}(t)}{N(t)}=\eta L_{I}^{*}=\eta\left(L-L_{F}^{*}\right)$. What's more, by definition, the equality must hold between the BGP growth rate of consumption and the rate of technological progress; thus $g^{*}=\dot{N}(t) / N(t)$. This pins down the equilibrium level of employment in the final good producing sector as

$$
L_{F}^{*}=\frac{\theta \eta L+\rho}{(1-\beta) \eta+\theta \eta}
$$

Then, the TFP growth rate of the entire economy weighted by the different share of labors among sectors can be expressed as the following formula:

$\frac{C(t)}{C(t)}=\sum_{i=1}^{3} \omega_{i} \cdot \frac{C\left(t_{i}\right.}{C(t)_{i}}=\frac{\omega_{1}}{\theta} \cdot\left((1-\beta) \eta L_{F}^{*}-\rho_{1}\right)+\omega_{2} \cdot \frac{\dot{A}_{S}}{A_{S}}+\omega_{3} \cdot 0$

The asymmetric level of technology diffusion between domestic manufacturing sector and modern service sector results in

$$
\frac{\dot{A_{S}}}{A_{S}}<\frac{1}{\theta} \cdot\left((1-\beta) \eta L_{F}^{*}-\rho_{1}\right)
$$

Hence, the slowdown of one country's TFP growth rate on its BGP can be disseminated into two channels: first, decreasing level of absorbing technological diffusion from FDI firms by domestic manufacturing firms lowers the value of coefficient $\eta$; second, the reallocation of labors among sectors, especially from sector with high TFP growth rate to sector with low TFP growth rate, will also deteriorate the entire TFP growth rate.

\subsection{The "New Normal" in China}

Since China's exchange rate reform in 2005, RMB appreciated accumulatively by $35 \%$. Concerning with the wage rigidity in labor market resulted from law of minimum wage, this appreciation, if not devastating, has heavily harmed the competitiveness of China's export. Taking into consideration a representative FDI firm in manufacturing sector, its rationale to establish a subsidiary in China is to transfer labor-intensive production chains and arbitrage the cheap factor price in China. Then through infra-firm trade, it can minimize its costs while attain the same quantity of products. This incentive of FDI firms to best allocate its production process in the worldwide scope is no longer consistent since the 2005 reform. Because of the wage rigidity in labor market and the appreciation of RMB, FDI firms specializing in purchasing on order face a rising cost of labor expenditure thus a decreasing return to capital investment. Now since they are less profitable, it is quite rational for them to exit from China and to switch to other host countries, thus also reducing their level of technological diffusion towards domestic manufacturing sector. From equation (3), the decrease in value of $\eta$ will lower the TFP growth rate of that country. From the first order derivative with respect to time $t$ to the logarithmic form of equation (6), when the economy of a country stabilizes on its equilibrium path, the TFP growth rate of the country should equal to the growth rate of nominal wage in that country. With the FDI firms switching their production location to other host countries, the TFP growth rate of China slows down gradually. In order to stabilize its economy to equilibrium state, China should slowdown its growth rate of nominal wage. However, the severe regulation on China's labor market invokes downward nominal wage rigidity, which cannot be flexible enough to fluctuate with the slowdown of TFP growth rate in China. In this extension, the "Ratchet Effect" on nominal wage largely contorts the equilibrium condition of the entire economy, exacerbating further the rising cost faced by FDI firms in China, thus reinforcing FDI firms to accelerate their process of switching production capacity to other host countries with cheaper labor cost, such as Vietnam, Thailand, Indonesia, and etc.

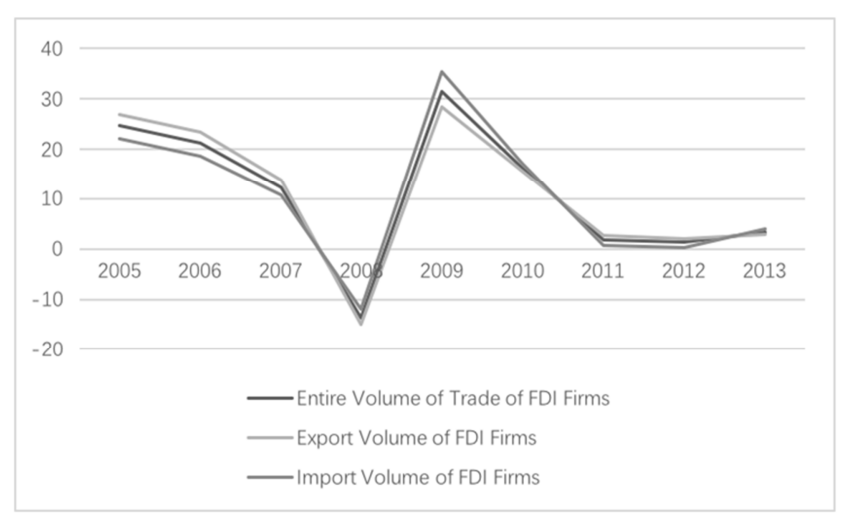

Data Source: National Bureau of Statistics of China.

Figure 15. The Growth Rate of FDI Firm's Export and Import Volume In China: 2005-2013.

As can be seen from Figure 15, the growth rate of export and import volume of FDI firms shows in general a significantly decreasing tendency. In 2005 , the level of growth rate of trade volume of FDI firms remained at a relatively high level at $20 \%$ to $30 \%$. However, so far until 2014 , the growth rate of trade volume of FDI firms stagnated and would even keep decreasing. In this round of slowdown in growth rate of trade volume of FDI firms, only in 2008 and 2009, could we see the increase in the growth rate of trade volume, which returned to its decreasing pattern afterwards. This decreasing tendency of the growth rate of trade volume reconciles with logic of this paper that the downward nominal wage rigidity in the labor market causes strong "Ratchet Effect" in China's nominal wage. In this extension, when the FDI firms face with the rising cost of labor by the appreciation of RMB, nominal 
wage is not flexible enough to offset the negative influence of currency appreciation. The continuously rising cost of labor forced the FDI firms to contract its production capacity in China and switch to other host countries with lower cost of labor. At the same time, the lower expected profitability of the FDI firms also deters those potential FDI firms with more advanced technology to give up establishing subsidiaries in China. Therefore, there exist two sources for the slowdown of growth rate of trade volume of FDI firms in China: first, the incumbent FDI firms mitigated their production capacity expansion and even contract and switch the stock production capacity; second, potential FDI firms with more advanced technology to give up establishing subsidiaries in China, hence also slows down the growth rate of trade volume via sluggish increase in intra-firm trade.

As a result, incumbent FDI firms shut down domestic factories and find new profitable host countries. This, then, exerts huge number of unemployment in the purchasing on order manufacturing sector. Since the purchasing on order attributes to the low end of international labor division, former workers in this sector do not have the innovative ability required by the domestic manufacturing sector. Consequently, this enormous quantity of unemployed people cannot be absorbed by the domestic manufacturing sector. Stressed and discouraged, it seems the unemployed has no alternative but to move back to rural areas. However, the continuum beneficial policies to agriculture sector and modern service sector, such as decent grain subsidies, lower entry barrier of modern service sector, and streamlined procedures of approval, wage rigidity in the modern service sector, have reshaped the labor force flow a bit. As a consequence, instead of just between manufacturing and the agriculture sectors, the reallocation of resources is extensive among all the three sectors: manufacturing, agriculture and modern service sectors.

Moreover, since the majority of FDI firms are specializing in purchasing on order, the shut down of FDI firms drive down, at the same time, both the quantity of export and import and thus the trade volume. In addition, the monetary issuance is also deeply affected by the sudden drops in current account surplus. Prior to the 2005 exchange rate reform, China experienced a continuum of trade surplus. In order to sustain her competitiveness in the international market, China increased its funds outstanding for foreign exchange in order to mitigate the appreciation pressure of RMB and bring the exchange rate back into the targeted corridor. Consequently, sustained trade surplus exerted huge amount of newly issued money supply, which is the key factor for the explanation of past high-level inflation rate between 2008 and 2012.

Last but not the least, this wave of shutdown of FDI firms, to some extent, has improved the current wealth distribution in China. The reason is that: it mostly happens in the coastal provinces that produce more than 85 percent of China's exports while inland provinces have kept relatively high rates, which, in turn, created convergence within the country.

Since FDI becomes less profitable, not only incumbent FDI firms exit, but also potential FDI firms with higher level of technology refuse to again take China as its host country. To this extent, China fails to continuously take advantage of the foreign technology diffusion and thus $\eta$, the coefficient of technology diffusion, decreases. It can be derived from equation (22) and equation (23) that when $\eta$ decreases, the growth rate $g^{*}$ also decreases.

It is quite intuitive to understand the mechanism of the slowdown of growth rate. Since its backward taking off and abundant labor endowment, on the one hand, China lacks enough expertise to innovate endogenously; On the other hand, China's cheap factor price of labor incurred strong incentives and attractions for FDI firms to bring in new technologies and produce locally to arbitrage cheap labor price. Through technology diffusion, imitation, and learning by doing, China finds its way into technology innovation. But, the current situation, such as appreciation of RMB, wage rigidity in the labor market, grain subsidies, citizen treatment to FDI firms, have mitigated its attraction to FDI firms and thus blocked her way to further take advantage of foreign technology diffusion. As it's known that on the BGP, growth rate per capita equals rate of TFP progress. Combined with the fact that the structural change of China's declining working-age population, the total GDP is going to decrease. This is quite consistent with the recent Chinese experience that the growth rate of GDP decreased from two digits to only approximately $7.4 \%$ per annum.

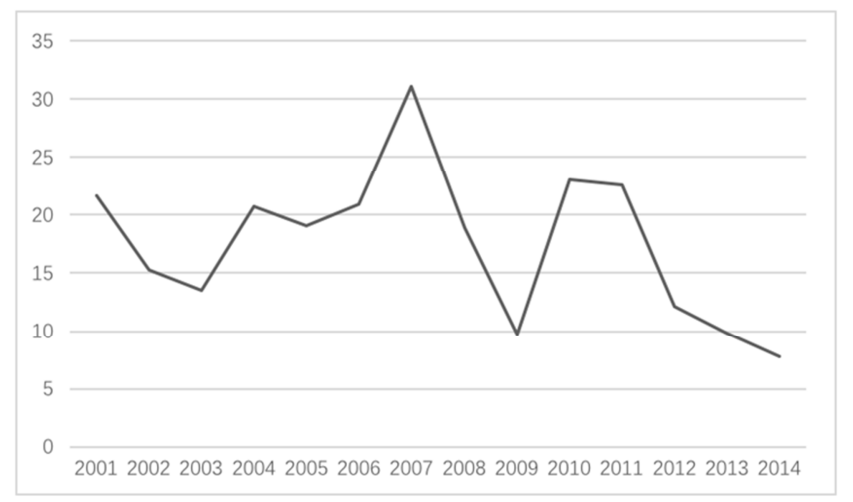

Data Source: National Bureau of Statistics of China.

Figure 16. The Growth Rate of China's Governmental Taxation Income: 2001-2014.

At the same time, great importance should be attached to the variation of share of consumptions in total GDP. In terms of Rostol's theory, the share of consumption should rise as the country grows from its economic taking off to the dimensional consumption period, thus a decreasing share of savings. But it seems quite another story with the growth experience in China. Last decade has witnessed halted even decreased consumption shares, only recently, has the share risen a bit. The observed consumption share can be attributed to the expansion and contraction of governmental expenditures. In terms of macroeconomic theories, long term expansion of governmental purchase will crowd out individual consumption thus prevent the economy from its taking off to the period of dimensional consumption, thus preventing the rising share of consumption, decreasing share of savings, and 
the growth of import volume. As a result, a rising consumption share cannot be observed. This is quite consistent with the China's experience. During the last decade, the taxation volume has been increasing at a two-digit rate per annum, which is also true of the governmental expenditure. Consequently, what is observed is the enlargement of governmental expenditure at the cost of contraction of consumption share. Recently, in order to cope with the downturn of economic growth in the context of weakened competitiveness in the international market, the Chinese government has no alternative but cut the level of taxations towards firms, households, and other institutions. This abatement of tax has increased the expectation of lifetime wealth of forward-looking households, thus contributing to the rise of consumption share recently.

As is shown from Figure 16, the growth rate of China's governmental taxation income has kept decreasing in recent years. The slowdown in the growth rate of taxation income increases the permanent income of household with forward horizons in their entire lifetime, thus increasing their current consumption and raising up the consumption share.

This completes the description of the "New Normal" in China.

\section{Quantitative Analysis}

In this section, this paper will try to use econometric approaches to check the causal relations between trade volume growth and TFP progress.

\subsection{Data and Model}

The rate of TFP progress has an interesting statistical relationship with the growth rate of trade volume. At the aggregate level, the timing of decrease in the rate of TFP progress mimics closely that of the drops in trade volume growth rate since 2005 . This paper documents this pattern by using OECD data from 1999 to 2011. The dataset allows the construction of a time-series analysis towards the causal relationship between rate of TFP progress and the growth rate of trade volume. According to the logic of this paper, the growth rate of trade volume is believed to have a strong relationship with the rate of change of intra-firm trade among FDI firms, thus offering a proper and satisfactory description of the change of technological diffusion from FDI firms. Therefore, the disclosure of the existence of causal relationship between growth rate of TFP and growth rate of trade volume is equivalent to manifest that the TFP growth rate of a country can be significantly influenced by technological diffusion from FDI firms. This exactly reconciles with the reason for China's entering of its phase of "New Normal".

The key variables in this model are GGDP and TRDVLM. GGDP, percent change from year ago of real GDP per capita, is used as a proxy to rate of TFP progress, since on the balanced growth path, the growth rate of GDP per capita equals rate of TFP progress. In this dataset, for variable GGDP, all observations range from $7.6 \%$ to $14.2 \%$, with a mean of $10 \%$, and a standard error of 1.8 . No missing point is declared.

TRDVLM, percent change from year ago of trade volume, is employed as a measurement of the magnitude of technology diffusion. The larger the trade volume is, the more technology diffusion from the outside world that is supposed to be seen. In this dataset, for variable TRDVLM, all observations range from $-30.8 \%$ to $127.5 \%$, with a mean of $19 \%$, and a standard error of 41.8. No missing point is declared.

In order to check the causal relationship between rate of TFP progress and the growth rate of trade volume, the method of co-integration is employed to figure out whether there exists the relationship of co-integration between the two variables in the long run, short run, or both. The procedures and models are as follows.

Consider first, whether the two are integrated of 1. This employs the method of unit root test, ADF (augment Dickey-Fuller test),

$$
G G D P_{t}=\delta_{0}+\delta_{1} G G D P_{t-1}+\mu_{t}
$$

with null hypothesis: $\delta_{1} \geq 1$. This is also true of variable TRDVLM.

Then, I run an OLS regression with the independent variable, GGDP, the dependent variable, TRDVLM, as the following,

$$
G G D P_{t}=\alpha_{0}+\alpha_{1} T R D V L M_{T}+\mu_{t}
$$

and check whether the residual $\hat{e}$ are stationary. From this process, the long run relationship between GGDP and TRDVLM, $\alpha_{1}$, can be attained.

Finally, the ECM (Error Correction Model) is used, which is mentioned by Davidson, Hendry, Srba, and Yeo in the year of 1978 to check the short-term relationship between GGDP and TRDVLM. The regression is as the following,

$$
\Delta G G D P_{t}=\beta_{0}+\beta_{1} \Delta T R D V L M_{t}+\beta_{2} \widehat{e_{t-1}}+\mu_{t}
$$

the coefficient $\beta_{1}$, depicts the short-run relationship between GGDP and TRDVLM.

\subsection{Results and Discussion}

Firstly, according to the results of unit root test from Table 1, since the null hypothesis cannot be rejected even at the $10 \%$ significant level, GGDP has a unit root. However, null hypothesis of DGGDP is easily rejected at the $5 \%$ significant level. Obviously, GGDP is integrated of 1;

Table 1. Dickey-Fuller Unit Root Test: GGDP.

\begin{tabular}{lllll}
\hline & Test Statistic & $\begin{array}{l}\mathbf{1 \%} \text { Critical } \\
\text { Value }\end{array}$ & $\begin{array}{l}\mathbf{5 \%} \text { Critical } \\
\text { Value }\end{array}$ & $\begin{array}{l}\mathbf{1 0 \%} \text { Critical } \\
\text { Value }\end{array}$ \\
\hline \multirow{2}{*}{ Z(t)_GGDP } & -1.945 & -3.750 & -3.000 & -2.630 \\
& MacKinnon approximate p-value for $\mathrm{Z}(\mathrm{t})=0.3110$ \\
& -3.186 & -3.750 & -3.000 & -2.630 \\
Z(t)_DGGDP & Mackinnon approximate p-value for $\mathrm{Z}(\mathrm{t})=0.0208$ \\
\hline
\end{tabular}


Table 2. Dickey-Fuller Unit Root Test: TRDVLM.

\begin{tabular}{|c|c|c|c|c|}
\hline & $\begin{array}{l}\text { Test } \\
\text { Statistic }\end{array}$ & $\begin{array}{l}1 \% \text { Critical } \\
\text { Value }\end{array}$ & $\begin{array}{l}5 \% \text { Critical } \\
\text { Value }\end{array}$ & $\begin{array}{l}10 \% \text { Critical } \\
\text { Value } \\
\end{array}$ \\
\hline \multirow{2}{*}{ Z(t)_TRDVLM } & -2.011 & -3.750 & -3.000 & -2.630 \\
\hline & \multicolumn{4}{|c|}{ MacKinnon approximate $\mathrm{p}$-value for $\mathrm{Z}(\mathrm{t})=0.2816$} \\
\hline \multirow{2}{*}{ Z(t)_DTRDVLM } & -3.571 & -3.750 & -3.000 & -2.630 \\
\hline & \multicolumn{4}{|c|}{ MacKinnon approximate $\mathrm{p}$-value for $\mathrm{Z}(\mathrm{t})=0.0063$} \\
\hline
\end{tabular}

Secondly, in the same line of reasoning from Table 2, since the null hypothesis cannot be rejected even at the $10 \%$ significant level for TRDVLM, that of DTRDVLM is easily rejected at the 5\% significant level. Thus, variable TRDVLM is also integrated of 1 .

Table 3. Co-Integration between GGDP and TRDVLM in the Long Run.

\begin{tabular}{|c|c|c|c|c|c|}
\hline & Coef. & Std. Err. & t & $\mathbf{P}>|\mathbf{t}|$ & [95\% Conf. Interval] \\
\hline TRDVLM & 0.0278984 & 0.0101512 & 2.75 & 0.019 & 0.00555590 .050241 \\
\hline CONS & 9.461689 & 0.4527201 & 20.90 & 0.000 & 8.46525910 .45812 \\
\hline \multirow{3}{*}{$\mathrm{Z}(\mathrm{t}) \mathrm{e}$} & $\begin{array}{l}\text { Test } \\
\text { Statistic }\end{array}$ & $\begin{array}{l}1 \% \text { Critical } \\
\text { Value }\end{array}$ & \multicolumn{2}{|c|}{$\begin{array}{l}5 \% \text { Critical } \\
\text { Value }\end{array}$} & $10 \%$ Critical Value \\
\hline & -2.626 & -3.750 & \multicolumn{3}{|c|}{$-3.000-2.630$} \\
\hline & \multicolumn{5}{|c|}{ MacKinnon approximate $p$-value for $Z(t)=0.0877$} \\
\hline
\end{tabular}

Thirdly, from Table 3 , since the residual $\hat{e}$ is almost stationary at the $10 \%$ significant level, it's reasonable to claim that variable GGDP and variable TRDVLM are co-integrated and there exists a long-term equilibrium relationship between the two. Consequently, the coefficient $\alpha_{1}$ from the OLS regression can be a good estimate of the relationship between GGDP and TRDVLM in the long run. The estimated coefficient is positive and highly statistically significant: a 10 percentage points larger increase in the trade volume is associated with an averagely 0.27 percentage points larger rate of TFP progress.

Table 4. Co-Integration between GGDP and TRDVLM in the Short Run.

\begin{tabular}{llllll}
\hline & Coef. & Std. Err. & $\mathbf{t}$ & $\mathbf{P}>|\mathbf{t}|$ & $\begin{array}{l}\text { [95\% Conf. } \\
\text { Interval] }\end{array}$ \\
\hline DTRDVLM & 0.0178016 & 0.0091942 & 1.94 & 0.085 & -.0029972 .0386004 \\
e & 1.248252 & 0.2814214 & 4.44 & 0.002 & .61163231 .884871 \\
CCONS & 10.04487 & 0.3129627 & 32.10 & 0.000 & 9.33690310 .75284 \\
\hline
\end{tabular}

Fourthly, from Table 4, the estimated coefficient given by ECM is also positive and highly statistically significant: a 10 percentage points larger increase in the trade volume is associated with an averagely 0.18 percentage points larger rate of TFP progress. This is a good estimate of the short-term relation between GGDP and TRDVLM.

Table 5. A Comparison of Co-Integration Models in both Short Run and Long Run.

\begin{tabular}{lll}
\hline & Long-run Model & Short-run ECM \\
\hline TRDVLM & $0.0278984^{* *}$ & \\
DTRDVLM & & $0.01780162^{*}$ \\
e & & $1.2482519^{* * *}$ \\
_CONS & $9.4616889^{* * *}$ & $10.044874^{* * *}$ \\
\hline
\end{tabular}

Note: $* \mathrm{p}<10 \% ; * * \mathrm{p}<5 \% ; * * * \mathrm{p}<1 \%$
A comparison between the long-term and short-term relationship could be seen from Table 5. It is quite reasonable that the GGDP is more sensitive to TRDVLM in the long run than in the short run: on the one hand, only on the balanced growth path, the equalization of rate of TFP progress and growth rate of real GDP per capita holds; on the other hand, the adoption and localization of newly diffused technology need time.

\section{Conclusion and Policy Recommendation}

\subsection{Conclusion}

This paper is based on a growth model augmented with asymmetric technology diffusions from FDI firms among various sectors and wage rigidity in the labor market. The model is consistent with salient features of the recent "New Normal" growth experience in China: slowdown of growth rate, low level of inflation and unemployment, decreasing returns on capital investment, extensive reallocation among agriculture, manufacturing and modern service sectors, rising share of consumption, improvement of wealth distribution, and reduced foreign surplus. An econometric model has been provided as empirical evidences to the theoretical model, with a quite supportive result: on the one hand, a 10 percentage points larger increase in the trade volume is associated with an averagely 0.27 percentage points larger rate of TFP progress in the long run; on the other hand, a 10 percentage points larger increase in the trade volume is associated with an averagely 0.18 percentage points larger rate of TFP progress in the short run.

A number of simplifications will be relaxed in future research. Particularly, this paper does not explore in depth the endogenous determinants of $\eta$, a coefficient describing technology diffusion from FDI firms. Growth theories of improvement of infrastructure and accumulation of human capital could shed new light to reinforce and complement the mechanism of the theory in this paper.

In spite of these limitations, it is conceivable that the theory explored here offers a useful tool for understanding one of the major puzzles in the China's "New Normal" growth experience: how can the slowdown of TFP progress and reduced growth rate of trade volume emerge simultaneously? Some commentators have tried to explain this puzzle by attributing it as a normal pattern of economic structural transition by attaching more importance to domestic demand instead of external demand, self-innovation instead of technology diffusion. While it is difficult to falsify theories relying on such artificially non-economic manipulation, this paper has provided substantial empirical evidences that corroborate the economic mechanism of the theory proposed above.

\subsection{Policy Recommendation}

This paper adopts a dynamic view and opens the black box for the reason of China's entering the phase of "New Normal". 
The finding of this paper is that the direct reason for China's entering of the phase of "New Normal" is attributed to the long-term decrease of technological diffusion from FDI firms and the exacerbating accumulation of nominal wage rigidity in the labor market. The two reasons above invoked a positive feedback effect under the shock of exchange rate reform in 2005, deteriorating the potential of China's TFP growth, which is leading China's entering of "New Normal" step by step. Without foreseeable changes, China's economy will trap into the phase of "New Normal" with larger depth. Therefore, this paper provides policy recommendations as "reversed manipulation", i.e., to adopt policy manipulation which has opposite effect compared with the exchange rate reform in 2005. This kind of manipulation needs not to be narrowed within the scope of exchange rate but any other manipulation that might offset the negative shock to international trade by exchange rate reform, thus promoting the competitiveness of a country in terms of cross-country trade.

This paper suggests policy recommendations different from other papers. By questioning whether the current economic structural transition can provide China with large enough positive shock to TFP growth rate to offset the negative shock exerted in the same way, this paper reveals the potential risks of the current policy recommendations from other papers and provokes critical thinking.

\section{References}

[1] Arrow K J. The economic implications of learning by doing [M]. Palgrave Macmillan UK, 1971.

[2] Bewley T F. Why wages don't fall during a recession [M]. Harvard University Press, 1999.

[3] Burgess R, Venables A. Towards a microeconomics of growth [M]. World Bank Publications, 2004.

[4] Coe D T, Helpman E, Hoffmaister A W. North-South R\&D Spillovers [J]. Cepr Discussion Papers, 1995, volume 107 (107): 134-149 (16).

[5] Coe D T, Moghadam R. Capital and trade as engines of growth in France: An application of Johansen's cointegration methodology [J]. Staff Papers-International Monetary Fund, 1993: 542-566.

[6] Davies G. 2014, Watch China's exchange rate policy, The Financial http://blogs.ft.com/gavyndavies/2014/02/25/watch-chinas-exc hange-rate-policy/

[7] Dickens W T, Goette L, Groshen E L, et al. How wages change: micro evidence from the International Wage Flexibility Project [J]. National Bank of Belgium Working Paper, 2006 (96).

[8] Dietmar Harhoff. R\&D and Productivity in German Manufacturing Firms [J]. Economics of Innovation \& New Technology, 1998, 6 (1): 29-50.

[9] Easterly W, Levine R. It's not factor accumulation: stylized facts and growth models [J]. 2002.

[10] Eaton J, Kortum S. International patenting and technology diffusion [R]. National Bureau of Economic Research, 1994.
[11] Hall R E, Jones C I. Why do some countries produce so much more output per worker than others? [R]. National bureau of economic research, 1999.

[12] Henderson J V. Chapter 24 - Urbanization and Growth [J]. Handbook of Economic Growth, 2005, 1 (05): 1543-1591.

[13] Howitt P, Aghion P. Capital accumulation and innovation as complementary factors in long-run growth [J]. Journal of Economic Growth, 1998, 3 (2): 111-130.

[14] Keller W. International technology diffusion. J Econ Lit [J]. Journal of Economic Literature, 2002, 42 (3).

[15] Klenow P, Rodriguez-Clare A. The neoclassical revival in growth economics: Has it gone too far? [M]//NBER Macroeconomics Annual 1997, Volume 12. MIT Press, 1997: 73-114.

[16] Knoppik C, Beissinger T. Downward nominal wage rigidity in Europe: an analysis of European micro data from the ECHP 1994-2001[J]. Empirical Economics, 2009, 36 (2): 321-338.

[17] Kraay A. Household saving in China [J]. The World Bank Economic Review, 2000, 14 (3): 545-570.

[18] Kuijs L. Investment and Saving in China [J]. Social Science Electronic Publishing, 2005: 1-20.

[19] Landes D S. The Unbound Prometheus [J]. General Information, 1969.

[20] Lewis W A. Economic development with unlimited supplies of labour [J]. The manchester school, 1954, 22 (2): 139-191.

[21] Lucas R E. On the mechanics of economic development [J]. Journal of monetary economics, 1988, 22 (1): 3-42.

[22] Lucas R E. Life Earnings and Rural-Urban Migration [J]. Journal of Political Economy, 2004, 112 (S 1): 29-29.

[23] Madden G, Savage S J. R \& D Spillovers, Information Technology and Telecommunications, and Productivity in Asia and the OECD [J]. Information Economics \& Policy, 2000, 12 (4): 367-392.

[24] Prescott E C. Lawrence R. Klein Lecture 1997: Needed: A Theory of Total Factor Productivity [J]. International Economic Review, 1998, 39 (3): 525-551.

[25] Romer P. Endogenous technological change [R]. National Bureau of Economic Research, 1989.

[26] Saggi K. Trade, foreign direct investment, and international technology transfer: A survey [J]. The World Bank Research Observer, 2002, 17 (2): 191-235.

[27] Tilford S. Rebalancing the Chinese economy [J]. Centre for European Reform, 2009.

[28] Tyers R. China After the Crisis: The Elemental Macroeconomics [J]. Asian Economic Journal, 2002, 15 (2): 173-198.

[29] Williamson J G. Migration and urbanization in the Third World [J]. 1986.

[30] Yang J, Zhang W, Tokgoz S. Macroeconomic impacts of Chinese currency appreciation on China and the Rest of World: A global CGE analysis [J]. Journal of Policy Modeling, 2013, 35 (6): 1029-1042. 
[31] Yang X, Borland J. A microeconomic mechanism for economic growth [J]. Journal of political economy, 1991: 460-482.

[32] Yang, Yao. (2013), “A New Normal, but with Robust Growth: China's Growth Prospects in the Next 10 Years", THINK TANK 20: Growth, Convergence and Income Distribution: The Road from the Brisbane G-20 Summit.
[33] Zyurt S, Main F A. Currency Undervaluation and Economic Rebalancing towards Services: Is China an Exception? [J]. China \& World Economy, 2013, 21 (1): 47-63. 